\title{
PERLINDUNGAN HUKUM TERHADAP KONSUMEN AKIBAT KERUGIAN YANG DITIMBULKAN OLEH PELAKU USAHA TOKO ONLINE DI INSTAGRAM
}

\author{
LEGAL PROTECTION AGAINST CONSUMERS DUE TO LOSS \\ INCURRED BY ONLINE STORE BUSINESSES ON INSTAGRAM
}

\author{
Andre Perdana Pebrian,S.I.P,.M.I.P.' ${ }^{1}$, Yidi Anjarina Vironika \\ Fakultas Hukum Universitas Malahayati Bandar Lampung \\ Email: andrepebrian@malahayati.ac.id, yidianjarina09@gmail.com
}

Dikirim 22 April 2021, Direvisi 12 Juni 2021, Disetujui 29 Juli 2021

\begin{abstract}
Abstrak: Manusia sebagai makhluk Economicus memiliki kebiasaan untuk selalu memenuhi kebutuhannya secara terus-menerus. Manusia saat ini dapat melakukan transaksi secara elektronik (e-commerce), hal ini memudahkan manusia dalam membeli suatu barang. Semakin berkembangnya teknologi, maka munculah suatu aplikasi instagram, dalam aplikasi tersebut manusia dapat memposting foto maupun video, di dalam aplikasi tersebut pelaku usaha toko online juga dapat menawarkan barang kepada konsumen secara online. Sehingga hal ini memungkinkan pelaku usaha toko online yang nakal dapat sewaktu-waktu membodohi konsumen yang tidak bertemu secara langsung dengan cara memberikan pernyataan informasi yang salah yang mengakibatkan kerugian yang ditimbulkan oleh pelaku usaha toko online di instagram. Perlindungan terhadap Konsumen dipandang secara materiil maupun formiil makin terasa sangat penting, mengingat makin lajunnya ilmu pengetahuan dan teknologi yang merupakan motor penggerak bagi produktifitas dan efisiensi produsen atas barang atau jasa yang dihasilkannya dalam rangka mencapai sasaran usaha. Dalam rangka mengejar dan mencapai kedua hal tersebut, akhirnya baik langsung atau tidak langsung, maka Konsumenlah yang pada umumnya merasakan dampaknya. Metode Penelitian yang akan digunakan dalam penulisan jurnal yaitu adalah jenis metode penelitian yang dilakukan dengan pendekatan yuridis normatif yaitu asas-asas hukum serta mengacu pada norma-norma hukum yang terdapat dalam penelitian pustakaan yaitu melakukan penelitian dengan mengggunakan data dari berbagai sumber seperti dari Undang-Undang, Buku, Internet dan Jurnal sehingga dapat dinilai relevan dengan permasalahan yang akan dibahas.
\end{abstract}

Kata kunci: Transaksi, Instagram, Konsumen.

\begin{abstract}
Humans as Economicus creatures have the habit of always meeting their needs continuosly. Humans today can conduct transaction electronically (e-commerce), this make it easir for humans to buy an item. With the development of technology, an instagram application appears, in that application humans can post photos and videos, in this application online shop business actors can also offer goods to consumers online. So that this allows naughty online shop busniess actors to fool consumers who do not meet in person by providing false information statements that result in losses incurred by online shop business actors on instagram. Consumers protection is seen materially and formally as increasingly felt very important, given the increasing speed of science and technology which is the driving force for the producctivity and efficiency of producers for the goods or services they produce in order to achieve business goals. In order to pursue and achieve these two things, ultimately either directly or indirectly, it is the Consumers who generally feel the impact. The research method that will be used in journal writing is a type of research method carried out with a normative juridical approach, namelylegal principles and referring to legal norms contained in library research, namely conducting research using data form various sources such as from the Act, Bokks, Internet and Journals so that they can be assessed as revelant to the issues to be dis cussed.
\end{abstract}

Keywords: Transaction, Instagram, Consumers.

\section{PENDAHULUAN}

Manusia $\begin{gathered}\text { sebagai makhluk } \\ \text { individu memiliki }\end{gathered}$ kehidupan
menyendiri namun manusia sebagai
makhluk sosial tidak dapat

melepaskan dirinya dari kelompok masyarakat. Sebagai individu manusia tidak dapat melakukan sesuatu yang diinginkannya hanya dalam perseorangan. Perubahan prilaku masyarakat tersebut dapat 
dilihat dalam berbagai sektor-sektor perkembangan yang ada. Selanjutnya, oleh karena perkembangan yang sangat cepat dan cepat tersebut di masyarakat pun penggunaan internet kini telah meluas kepada perkembangan penggunaan media sosial. Adapun dengan adanya/perkembangan internet dan media sosial ini, tentunya baik secara langsung maupun tidak membawa dampak yang cukup signifikan, atau dengan kata lain adalah cukup berpengaruh, terhadap segala aspek kehidupan masyarakat, dan ini tidaklah berdampak pada masyarakat tertentu saja, melainkan juga berdampak pada seluruh masyarakat di dunia, karena perkembangan internetdan media sosial ini memanglah perkembangan teknologi yang mendunia.

Timbulnya kelalaian dalam bertransaksi secara online saat ini membuat terjadinya kesenjangan antara peraturan perundangundangan yang mengatur mengenai bagaimana transaksi online tersebut dengan kenyataan yang ada di masyarakat. Maka dari itu tanggung jawab pelaku usaha/toko online tersebut perlu diperhatikan, hal itulah yang menyebabkan saya mengangkat judul "Perlindungan Hukum Terhadap Konsumen Akibat Kerugian Yang Ditimbulkan Oleh Pelaku Usaha Toko Online Di Instagram"

Dalam uraian latar belakang yang dipaparkan diatas maka dapat di tarik rumusan masalah sebagai berikut :

1. Bagimanakah Pengaturan Hukum JualBeli Barang Melalui/Electronic Commerce (E-Commerce)?

2. Bagaimana Perlindungan Hukum Bagi Konsumen yang mengalami kerugian akibat jual beli barang eletronik commerce (E-Commercce) ?

Adapun tujuan yang dicari dari penulisan tulisan ini ialah agar mengetahui bagaimana pengaturan hukum jual beli barang online yang mengalami kerugian yang ditimbulkan oleh pelaku usaha toko online melaksanakan transaksi secara online serta apa saja perlindungan hukum demi melindungi konsumen.

\section{LANDASAN TEORI}

\section{Pengertian E-Commerce}

Menyangkut konsumen (consumers), manufaktur (manufacturers), service provider, dan perdagangan perantara (intermediaries) dengan menggunakan jaringan-jaringan komputer (computer networks), yaitu E- Commerce sudah meliputi seluruh spectrum kegiatan komersial. Onno w.Purbo dan Aang Arif Wahyudi mencoba menggambarkan $E$ Commerce sebagai suatu cakupan yang luas mengenai teknologi, proses dan praktik yang dapat melakukan transaksi bisnis tanpa menggunakan kertas sebagai sarana mekanisme transaksi . Hal ini bisa dilakukan dengan berbagai cara seperti melalui e-mail atau bisa melalui World Wibe Web.

Menurut WTO E-Commerce adalah suatu proses meliputi produksi, ditribusi, pemasaran, penjualan dan pengiriman barang serta jasa melalui Elektronis. Sedangkan menurut para akademisi yang mendefinisikan $E$ - Zantara penjual dan pembeli atau pihak-pihak lainnya dalam hubungan kontrak yang menggunakan media elektronik atau digital yang dalam prosesnya tidak diperlukan temu muka dan transaksi dilakukan secara lintas batas. Sarana yang memungkinkan dilakukannya penjual dan pembelian produk dan infomasi melalui internet dan layanan-layanan online lainya.

E-commerce merupakan bidang yang multidisipliner (multidiciplinary) yang mencangkup bidang-bidang teknik seperti jaringan data telekomunikasi, pengamanan, penyimpanan, dan pengambilan data (retrieval) dari multi media, bidangbidang bisnis seperti pemasaran (marketing), pembelian dan penjualan ( Procurement and purchasing), penagihan dan pembayaran (billing and payment), manajemen jaringan ditribusi (supply chain 
management), dan aspek-aspek hukum seperti information privacy, hak milik intelektual (intelectual property), perpajakan (taxation), pembuatan perjanjian, dan penyelesaian hukum lainnya. Jadi secara singkat dapat dideskripsikan, bahwa E-commerce adalah suatu bentuk bisnis modern melalui sarana internet.

\section{Legalitas Transaksi E-Commerce Melalui Media Internet (Instagram)}

Jual beli produk (barang/jasa) yang dilakukan melalui media internet dimungkinkan untuk dilakukan karena memang sampai saat ini tidak ada larangan akan hal tersebut di Indonesia. Pada prinsipnya (dengan beberapa pengecualian seperti pada Pasal 5 ayat (4) UndangUndang Nomor 11 Tahun 2008 tentang Informasi dan Transaksi Elektronik- UU ITE), penggunaan media instagram atau suatu media elektronik lainnya untuk transaksi jual beli produk diserahkan kepada kebebasan para pihak untuk menentukannya (tergantung dari kesepakatan antara penjual dan pembeli). Pasal 19 UU ITE menyebutkan bahwa: "Para pihak yang melakukan Transaksi Elektronik harus menggunakan Sistem Elektronik yang disepakati." Pasal 47 Peraturan Pemerintah No. 82 Tahun 2012 tentang Penyelenggaraan Sistem dan Transaksi Elektronik ("PP PSTE").

Syarat Subjektif yang mana jika tidak terpenuhi maka perjanjian dapat dibatalkan oleh salah satu pihak (selama belum ada pembatalan makaperjanjian tetap sah), yaitu:

a. Adanya kesepakatan para pihak mengenai harga dan produk, tanpa ada paksaan, kekhilafan maupun penipuan;

b. Kecapakan para pihak yang membuat perjanjian. Pada dasarnya orang yang sudah dewasa, sehat akal pikiran dan tidak dilarang oleh undang- undang (seperti tidak dinyatakan pailit oleh pengadilan) adalah cakap menurut hukum. Sedangkan, "Dewasa" berdasarkan Pasal 330 KUHPerdata adalah berusia sudah 21 tahun atau sudah/pernah menikah.

Syarat objektif yang mana jika tidak terpenuhi maka perjanjian batal demi hukum, dianggap tidak pernah ada perjanjian sehingga tidak memiliki kekuatan mengikat secara hukum, yaitu:

a. Produk yang merupakan objek perjanjian harus tertentu (definite) dan dapat dilaksanakan (possible).

b. Sebab yang halal (lawful), isi dan tujuan dari perjanjian jual beli tersebut tidak bertentangan dengan peraturan perundang-undangan, Kecakapan para pihak yang membuat perjanjian.

Pada dasarnya orang kesusilaan dan ketertiban umum. Sebagai contoh: jual beli dilakukan bukan untuk barang yang dilarang oleh peraturan perundang undangan (contohnya bukan barang illegal) Informasi elektronik berupa isi percakapan/komunikasi melalui instagram antara penjual dengan pembeli dapat dijadikan salah satu alat untuk membuktikan dan menerangkan perjanjian yang terjadi antar para pihak. Pasal 5 ayat (1) UU ITE menyebutkan bahwa: "Informasi Elektronik dan/atau Dokumen Elektronik dan/atau hasil cetaknya merupakan alat bukti hukum yang sah." Jadi, suatu transaksi jual beli tidak akan disangkal keabsahannya hanya karena bukti transaksi jual belinya sematamata dalam bentuk elektronik.

\section{Jenis dan Interaksi E-Commerce}

Pada dasarnya perdagangan/transaksi $E$ Commerce dapat di kelompokkan menjadi 2 (dua) bagian besar yaitu : transaksi Busines to Business ( $B$ to B), dan Business to Consumer ( $B$ to $C$ ) 4 . Dua kelompok inilah yang menyelimuti hamper semua transaksi E-Commerce yang ada. Business toBusiness merupakan system komunikasi bisnis on-line antar pelaku bisnis. Para pengamat E-Commerce mengakui akibat terpenting adanya sistem komersial yang 
berbasis web tampak pada transaksi Business to Business.

\section{a. Bisnis ke Bisnis (Business to Business)}

Bisnis ke bisnis merupakan sistem komunikasi bisnis antar pelaku bisnis atau dengan kata lain transaksi secara elektronik antar perusahaan (dalam hal ini pelaku bisnis) yang dilakukan secara rutin dan dalam kapasitas atau volume produk yang besar. Aktivitas E-Commerce dalam ruang lingkup ini ditujukan untuk menunjang kegiatan para pelaku bisnis itu sendiri. Pebisnis yang mengadakan perjanjian tentu saja adalah para pihak yang bergerak dalam bidang bisnis yang dalam hal ini mengikatkan dirinya dalam suatu perjanjian untuk melakukan usaha dengan pihak pebisnis lainnya. Pihakpihak yang mengadakan perjanjian dalam hal ini adalah Internet Service Provider (ISP) dengan website atau keybase (ruang elektronik), ISP itu sendiri adalah pengusaha yang menawarkan akses kepada internet.

Sedangkan internet merupakan suatu jalan bagi komputer- komputer untuk mengadakan komunikasi bukan merupakan tempat akan tetapi merupakan jalan yang dilalui. Dilihat dari karakteristiknya, transaksi E-Commerce $B$ to $B$, mempunyai karakteristik sebagai berikut :

1. Tranding partners yang sudah saling mengetahui dan antara mereka sudah saling terjalin hubungan yang berlangsung cukup lama. Pertukaran informasi hanya berlangsung di antara mereka dan karena sudah sangat mengenal, maka pertukaran informasi tersebut dilakukan atas dasar kebutuhan dan kepercayaan;

2. Pertukaran data dilakukan secara berulang-ulang dan berskala dengan format data yang telah disepakati. Jadi, service yang digunakan antara kedua sistem tersebut sama dan menggunakan standar yang sama;

3. Salah satu pelaku tidak harus menunggu patner mereka lainnya untukmengirim data; dan

4. Model yang umum digunakan adalah pear to pear, di mana processing intelegance dapat didistribusikan di kedua pelaku bisnis.

\section{b. Bisnis ke Konsumen (Business To Consumer)}

Business to consumer dalam $E$ Commerce merupakan suatu transaksi bisnis secara elektronik yang dilakukan pelaku usaha dan pihak konsumen untuk memenuhi suatu kebutuhan tertentu dan pada saat tertentu. Dalam transaksi bisnis ini produk yang diperjualbelikan mulai produk barang dan jasa baik dalam bentuk berwujud maupun dalam bentuk elektronik atau digital yang telah siap untuk dikonsumsi.

Business to Consumer ( $B$ to $C$ ) merupakan transaksi jual beli melalui internet antara penjual barang dengan konsumen (end user). Business to Consumer dalam Ecommerce relatif banyak ditemui dibandingkan dengan Business to Business. Dalam transaksi $E$ Commerce jenis $B$ to $C$, hampir semua orang dapat melakukan transaksi baik dengan nilai transaksi kecil maupun besar dan tidak dibutuhkan persyaratan yang rumit. Konsumen dapat memasuki internet dan melakukan pencarian (search) terhadap apa saja yang akan dibeli, menemukan web site, dan melakukan transaksi.

Dalam transaksi ini, konsumen memiliki bargaining position yang lebih baik dibanding dengan perdagangan konvensional karena konsumen memperoleh informasi yang beragam dan mendetail. Kondisi tersebut memberi banyak manfaat bagi konsumen karena kebutuhan akan barang dan jasa yang diinginkan dapat terpenuhi. Selain itu juga terbuka kesempatan untuk memilih aneka jenis dan kualitas barang dan jasa sesuai dengan keinginan dan kemampuan finansial konsumen dalam waktu yang relatif efisien. Karakteristik 
transaksi E-Commerce Business to

Consumer adalah sebagai berikut :

a) Terbuka untuk umum, di mana informasi disebarkan secara umum pula; Service yang dilakukan juga bersifat umum sehingga mekanismenya dapat digunakan oleh banyak orang. Contohnya, karena sistem web sudah umum dikalangan masyarakat, maka sistem yang digunakan adalah sistem web pula;

b) Service yang diberikan berdasrkan permintaan konsumen berinisiatif sedangkan produsen harus siap memberikan respon terhadap inisiatif konsumen;

c) Sering dilakukan pendekatan clientserver, yang mana konsumen di pihak klien menggunakan sistem yang minimal (berbasis web) dan pihak penyedia barang atau jasa (business procedure) berada pada pihak server.

\section{Tahap - Tahap Transaksi Konsumen}

Yang dimaksud dengan transaksi konsumen adalah suatu proses terjadinya peralihan pemilikan atau penikmatan barang atau jasa dari pelaku usaha penyedia barang dan/atau jasa kepada konsumen. Tahap-tahap transaksi konsumen yang lazim terjadi yaitu:

\section{a) Tahap Pra-Transaksi Konsumen}

Pada tahap pra-transaksi konsumen, transaksi (pembelian, penyewaan, peminjaman, pemberian hadiah komersial dan sebagainya)belum terjadi. Konsumen masih mencari keterangan dimana barang atau jasa kebutuhannya dapat ia peroleh, berapa harga dan apa pula syarat-syarat yang ia harus penuhi, serta mempertimbangkan berbagai fasilitas atau kondisi dari transaksi ia inginkan. Dalam hal ini pelaku usaha sebagai penyedia atau penjual, harus menyediakan informasi yang jujur dan tidak menyesatkan berkaitan dengan barang dan/atau jasa yang ditawarkan. Oleh karena, informasi tersebut akan menjadi bahan pertimbangan bagi konsumen sebelum memutuskan untuk melakukan pembelian.

Pentingnya penyampaian informasi yang benar terhadap konsumen mengenai suatu produk, agar konsumen tidak salah terhadap gambaran mengenai suatu produk tertentu. Penyampaian informasi terhadap konsumen tersebut dapat berupa representasi, peringatan maupun berupa intruksi.

\section{b) Tahap Transaksi Konsumen}

Pada tahap ini transaksi peralihan suatu barang ataupun penyelenggaraan jasa dari pelaku usaha kepada konsumen telah terjadi. Konsumen dalam hal ini, sudah terikat dengan berbagai persyaratan guna memperoleh barang atau jasa bersangkutan misalnya mengenai persyaratan pembayaran, harga, dan sebagainya. Faktor lain yang juga berpengaruh pada konsumen dalam tahap ini adalah beberapa praktek bisnis yang dijalankan pengusaha untuk mempertahankan atau meningkatkan pemasaran produk usahanya atau penyerapan produknya oleh masyarakat. Permasalahan yang sering timbul dalam tahap transaksi konsumen adalah pada perikatan yang telah disepakati oleh pelaku usaha dan konsumen. Terdapat perjanjian dengan syarat-syarat baku, terutama perjanjian dengan syarat-syarat baku yang ditentukan secara sepihak.

\section{c) Tahap Purna-Transaksi Konsumen}

Tahap ini disebut juga tahap purnajual. Pada tahap ini konsumen mulai memanfaatkan barang dan/atau jasa yang diperolehnya dari transaksi dengan pelaku usaha bersangkutan. Kepuasan konsumen atau kekecewaannya berkenaan dengan transaksi yang diselenggarakan dapat menjadi kenyataan. Kepuasaan konsumen akan menyebabkan konsumen untuk selanjutnya setia dan tidak beralih dari merek barang atau jasa tertentu, sehingga pelaku usaha bersangkutan akan dapat mempertahankan langganannya. 
Sebaliknya, keadaan menjadi berbeda apabila konsumen. merasa tidak puas terhadap kegunaan dan/atau pemakaian dari suatu barang atau penyelenggaraan jasa yang diperoleh dari pelaku usaha. Dalam hal ini konsumen merasakan kerugian dari penggunaan barang dan/atau jasa bersangkutan. Konsumen yang merasa mengalami suatu kerugian lazimnya mengajukan suatu keluhan kepada pelaku usaha tersebut. Pelaku usaha tetap harus memberikan perlindungan dan pelayanan yang baik atas keluhan yang diajukan oleh konsumen dalam tahap purna-transaksi ini.

Berkaitan dengan hal itu, UUPK memberikan pengaturan atas tindakan yang harus dilakukan oleh pelaku usaha dalam tahap purna transaksi, antara lain :

1. Pasal 7 huruf f "Pelaku usaha wajib memberi kompensasi, ganti rugi dan/atau penggantian atas kerugian akibat penggunaan, pemakaian dan pemanfaatan barang dan/atau jasa yang diperdagangkan".

2. Pasal 19 ayat (1) "Pelaku usaha bertanggung jawab memberikan ganti rugi atas kerusakan pencemaran dan/atau kerugian konsumen akibat mengkonsumsi barang dan/atau jasa yang dihasilkan atau diperdagangkan".

3. Pasal 25 ayat (1) "Pelaku usaha yang memproduksi barang yang pemanfaatannya berlanjutan dalam batas waktu sekurang-kurangnya 1 tahun wajib menyediakan suku cadang dan/atau fasilitas purna jual dan wajib memenuhi jaminan atau garansi sesuai dengan yang diperjanjikan".

4. Pasal 26 "Pelaku usaha yang memperdagangkan jasa wajib memenuhi jaminan dan/atau garansi yang disepakati dan/atau diperjanjikan”.

Tahap-tahap diatas tidaklah secara tegas terpisah satu sama lain. Mungkin saja tahap pertama dan kedua langsung terjadi dalam satu kegiatan transaksi konsumen.

\section{d) Bentuk Pelanggaran Hak Konsumen}

Seperti diketahui bahwa UUPK menetapkan tujuan perlindungan kosumen antara lain adalah untuk mengangkat harkat kehidupan kosumen, maka untuk maksud tersebut berbagai hal yang membawa akibat negatif dari pemakaian barang dan atau jasa harus dihindarkan dari aktivitas perdagangan pelaku usaha. Sebagai upaya untuk menghindarkan akibat negatif pemakaian barang dan atau jasa tersebut, UUPK menentukan berbagai larangan bagi pelaku usaha yang terdiri dari 10 pasal, dimulai dari Pasal 8 sampai dengan Pasal 7.

Dalam pasal 8 yang termasuk perbuatanperbuatan yang dilarang dilakukan pelaku usaha pelaku usaha dilarang memproduksi dan atau memperdagangkan barang dan atau jasa yang ;

a) Tidak memenuhi atau tidak sesuai dengan standar yang dipersayartkan dan ketentuan peraturan perundangundangan.

b) Tidak sesuai dengan berat bersih, isi bersih atau netto, dan jumlah dalam hitungan sebagaimana yang dinyatakan dalam label atau etiket barang tersebut.

c) Tidak sesuai dengan ukuran, takaran, timbangan dan jumlah dalam hitungan menurut ukuran yang sebenarnya.

d) Tidak sesuai dengan kondisi, jaminan keistimewaan atau kemanjuran sebagaimana dinyatakan dalam label, etiket atau keterangan barang dan atau jasa tersebut.

e) Tidak sesuai dengan mutu, tingkatan, komposisi, proses pengolahan, gaya, mode, atau penggunaan tertentu sebagaimanadinyatakan dalam label atau keterangan barang dan atau jasa tersebut.

f) Tidak sesuai dengan janji yang dinyatakan dalam label, etiket, keterangan, iklan atau promosi penjualan barang.

Pelaku usaha dilarang memperdagangkan barang yang rusak, cacat atau bekas dan tercemar tanpa 
memberikan informasi secara lengkap dan benar atas barang dimaksud.

Pelaku usaha dilarang memperdagangkan sediaan farmasi dan pangan yang rusak, cacat atau bekas atau tercemar, dengan atau tanpa memberikan informasi secara lengkap dan benar.

Pelaku usaha yang melakukan pelanggaran pada ayat (1) dan ayat (2) dilarang memperdagangkan barang dan atau jasa tersebut serta wajib menariknya dari peredaran.

\section{Pengaturan Hukum Jual-Beli Barang Melalui Electronic Commerce (E-Commerce)}

Jual beli dalam arti sebenarnya adalah kegiatan menukar barang yang mempunyai daya tarik, penukarannya bukan silver dan bukan pula perunggu, bendanya dapat di tawar dan ada seketika (tidak ditangguhkan), tidak merupakan utang baik benda itu ada dihadapan pembeli maupun tidak, barang yang sudah diketahui wujud dan bentuknya atau sudah diketahui terlebih dahulu. Proses jual beli barang adalah segala kegiatan umum yang dilakukan oleh seorang disebut dengan penjual dengan seorang yang lain disebut dengan pembeli, dengan menggunakan metode umum tertentu yang menyatakan kepemilikan untuk selamanya dan didasari atas saling merelakan.

Proses atau transaksi online yang terjadimelalui dunia maya berbeda dengan transaksi seperti dipasar biasa pada umumnya. Dalam hal ini pedagang dan pembeli bisa berbicara secara langsung atau berinteraksi secara langsung. Transaksi lewat dunia maya terjadi dimana pedagang dan pembeli tidak bisa bertemu langsung hanya dengan menggunakan digital signature atau instrumen-instrumen elektronik lain sebagai alat dalam transaksi perdagangan. Transaksi dalam dunia maya terjadi ketika ada dua orang yang mana salah satu orang berjanji kepada orang yang lain untuk melakukan sesuatu. Agar tidak terjadi kesalahpahaman antar kedua belah pihak untuk melakukan suatu jual beli di dalam dunia maya. Perkembangan era globalisasi saat ini membuat kemajuan teknologi juga semakin canggih, pada era ini kemajuan teknologi didukung dengan berbagai fitur aplikasi yang memudahkan seluruh orang berkomunikasi dengan jarak jauh. Dampak positif dari berkembangnya kemajuan teknologi membuat pelaku usaha toko online dengan mudah dapat menawarkan barang dengan konsumen. Masyarakat Indonesia memiliki daya konsumtif yangcukup besar apabila dibandingkan dengan negara-negara yang ada di Negeri ini. Proses perubahan pola kehidupan masyarakat di negara berkembang yaitu dimana pola kehidupan yang dulunya adalah masyarakat agraris lambat laun berubah menjadi negara industri. Hal ini juga terpengaruh oleh adanya perkembangan teknologi yang ada pada zaman ini, majunya teknologi menyebabkan pula majunya peningkatan volume produksi barang yang dibutuhkan.

Transaksi elektronik (ecommerce) saat ini memang sedang booming dikalangan masyarakat. $E$ commerce sendiri dapatdidefinisikan sebagai segala sesuatu bentuk suatu transaksi perdagangan maupun perniagaan dengan menggunakan media elektronik. Didalam transaksi elektronik (e-commerce) pelaku usaha toko online dengan konsumen diketahui tidak bertemu secara langsung hal inilah yang menyebabkan sesuatu hal yang baik maupun buruk bisa terjadi didalam melakukan transaksi secara online tersebut.

Pasal 1 angka (1) UUPK menyatakan definisi dari perlindungan konsumen tersebut yaitu "Perlindungan Konsumen adalah segala upaya yang menjamin 
adanya kepastian hukum untuk memberi perlindungan kepada konsumen" berdasarkan ketentuan diatas konsumen mendapatkan perlindungan hukum dalam melakukan transaksi perdagangan barang yang diketahui didalam melakukan transaksi jual-beli perdagangan maupun perniagaan dibutuhkan setidaknya 2 (dua) pihak yang melakukannya, 2 (dua) pihak yang dimaksud adalah pihak pertama yaitu peyelenggara perdagangan dan perniagaan tersebut yang menyajikan barang, dan pihak kedua yang dimaksudkan adalah para pengguna barang yang disediakan oleh penyelengara perdagangan dan perngiaan tersebut.

Pertanggung jawaban yang didapatkan oleh konsumen seharusnya dibebankan oleh pelaku usaha toko online yang menyebabkan suatu kerugian akibat kesalahan maupun kelalaian yang diakibatkan oleh pelaku usaha toko online tersebut. Perlindungan Konsumen memiliki istilah yang berkaitan dengan perlindungan hukum, oleh karena itu perlindungan konsumen mengandung aspek hukum. Perlindungan hukum merupakan perlindungan yang diberikan hukum terkait mengenai hak dan kewajiban manusia. Didalam Pasal 4 UUPK yaitu mengenai suatu hak atas kenyamanan, maupun keamanan yangdidapatkan oleh para konsumen yang dilanggar oleh para pelaku usaha harus secara tegas dipertanggung jawabkan oleh pelaku usaha tersebut.

$$
\text { Pelanggaran yang dilakukan }
$$
oleh pelaku usaha toko online tersebut memberikan kenyataan bahwa sebenarnya implementasi hukum yang didapatkan melalui UUPK. Selain Pasal 4 yang salah satunya mengatur tentang hak kenyaman para konsumen, kejanggalan dalam implementasi hukum pada UUPK tersebut juga terdapat pada Pasal 7 yang dimana didalam Pasal 7 tersebut dijelaskan bahwa pelaku usaha mewajibkan memberikan informasi diskripsi barang atau jasa yang ditawarkan dengan benar, jujur, dan juga sesuai mengenai kondisi suatu barang maupun jasa yang diperjual-belikan oleh pelaku usaha toko online tersebut.

Kenyamanan dalam UUPK tidak menjelaskan dengan tegas apa saja hak kenyaman yang didapatkan oleh konsumen dan sampai mana konsumen tersebut dapat dikatakan "nyaman" sebagai konsumen. Selain diatur didalam UUPK, pemberian informasi yang benar, jelas dan sesuai dengan keadaan barang maupun jasa tersebut juga dijelaskan dalam UU ITE, yaitu dalam ketentuan Pasal 28 ayat (1) menyatakan bahwa apabila seseorang melakukan penyebaran berita bohong yang tidak memiliki hak untuk menyebarkan dan dapat menyesatkan seseorang dalam melakukan kerugian terhadap transaksi online maka dapat dihukum sesuai dengan Pasal 45 ayat (2) UU ITE yang menyatakan apabila seseorang memenuhi unsur sebagaimana yang dimaksudkan dengan Pasal 28 ayat (1) dan (2) maka dapat dipidanakan dengan pidana penjara paling lama 6 (enam) tahun dan denda paling banyak Rp.1.000.000.000,00 (satu milyar rupiah).

\section{Perlindungan Hukum Bagi} Konsumen yang mengalami kerugian akibat jual beli barang eletronik commerce (E-Commercce)

Bagi banyak orang jual-beli didunia maya merupakan suatu tren atau fashion baru yang sedikit dikenal oleh banyak 
orang. Masih banyak orang yang berfikir bahwa jual beli didunia maya ini sama dengan kegiatan jual-beli alat-alat mewah dan mahal dan hanya orang-orang tertentu saja yang bisa beli. Oleh karena itu dalam hal ini penulis berusaha mencoba menjelaskan dari pengertian dari transaksi online didunia maya tersebut. Dalam pengertian ini merupakan suatu kegiatan umum yang dilakukan antar pedagang dan pembeli atau dengan pihak lain dalam hubungan perjanjian yang sama untuk mengirimkan beberapa barang atau pelayanan jasa. Kegiatan jual-beli online ini terdapat didalam media elektronik yang secara fisik tidak perlu ada pertemuan bagi para pihak yang melakukan jual-beli online dan keberadaan media ini didalam sistem tertutup. Dari beberapa pengertian yang ditawarkan dan digunakan oleh berbagai kalangan masyarakat, terdapat kesamaan dari masing-masing pengertian tersebut. Kesamaan tersebut memperlihatkan bahwa jual-beli online mempunyai sifatsifat sebagai berikut:

a) Terjadinya kegiatan percakapan transaksi antar dua orang;

b) Adanya kegiatan tukar menukar barang atau informasi;

c) Internet adalah alat paling penting dalam proses perdagangan.

Tanggung jawab owner usaha terhadap pembeli dalam kegiatan jual-beli melalui internet memang secara umum belum diatur dengan baik dalam Undang-Undang perlindungan konsumen dan UndangUndang informasi dan transaksi elektronik. Dalam UUPK hanya mengatur jual-beli secara tradisional seperti dipasar sedangkan UU ITE mengatur tentang transaksi elektronik saja tidak ada tertulis khusus untuk jual-beli secara detail. Dan kelemahan inilah yang menjadi faktor utama yang mempersulit masyarakat umum dalam menuntut ganti rugi pemilik situs usaha dalam jual-beli online melalui dunia maya internet jika terjadi kerugian bagi masyarakat umum atau konsumen Sehubungan dengan pertanggungjawaban dalam transaksi jual beli online melalui dunia maya internet maka owner usaha tetap dapat ditagih atau dituntut pertanggungjawaban, apalagi kalau produk yang ditransaksikan itu tidak sesuai keinginan si pemesan dan merugikan masyarakat yang membeli barang tersebut. Pada UU ITE, tidak dengan khusus mengatur tentang jual beli. Faktor culture budaya masyarakat Indonesia yang kurang memahami tentang hak perlindungan sevagai pembeli dan tanggungjawab si owner atau pelaku usaha itu sendiri yang kurang menyebabkan masalah perlindungan kosumen menjadi hal yang biasa saja. Ditambah lagi faktor lembaga seperti YKLI dan LSM yang turut mewujudkan perlindungan kosumen di Indonesia berfungsi sebagaimana mestinya.

\section{Jenis dan Interaksi $E$-Commerce}

Pada dasarnya, perdagangan/transaksi E-Commerce dapat di kelompokkan menjadi 2 (dua) bagian besar yaitu : transaksi Busines to Business ( $B$ to $B)$, dan Business to Consumer ( $B$ to $C$ ) 4 . Dua kelompok inilah yang menyelimuti hamper semua transaksi E-Commerce yang ada. Business toBusiness merupakan system komunikasi bisnis on-line antar pelaku bisnis. Para pengamat $E$ Commerce mengakui akibat terpenting adanya system komersial yang berbasis web tampak pada transaksi Business to Business.

\section{METODOLOGI}

Penulisan pada jurnal ini ialah jenis penelitian hukum yuridis normatif dengan menggunakan objek kajian membandingkan ketentuan hukum normatif (Undang-Undang) dengan implementasi nya pada setiap peristiwa hukum yang terjadi dilingkungan masyarakat sehingga penelitian ini meliputi kesenjangan dalam teori dengan praktek nya dalam masyarakat, dengan menggunakan pendekatan fakta (the fact 
approach) artinya pendekatan ini melihat fakta yang ada di masyarakat dan kemudian dikaitkan dengan peraturan perundangundangan.

\section{HASIL DAN PEMBAHASAN}

Berdasarkan uraian pembahasan, perlindungan hukum bagi pembeli atau konsumen yang mengalami kerugian akibat jual beli electronic commerce dalam UU ITE telah diatur dalam Pasal 28 ayat 1 mengenai kerugian konsumen dalam e-commerce. Sebagaimana dimaksudkan pada pasal 19 UUPK yang dimaksud mengatur tanggung jawab ganti rugi. Tanggung jawab pelaku usaha terhadap pembeli dalam jual beli online melalui dunia maya internet memang secara umum belum diatur baik dalam undang-undang perlindungan konsumen maupun undang-undang informasi dan transaksi elektronik Dalam UUPK itu sendiri hanya mengatur jual-beli secara tradisional sedangkan UU ITE mengatur tentang transaksi elektronik pada umumnya.

Pemerintah sebagai regulator sekaligus penyelenggara sistem pengadaan e-commerce wajib membuat dan mensosialisasikan peraturan hukum yang mengikat bagi pelaku usaha dan konsumen guna menghindari dari ketidakpastian hukum yang ada. Hal ini juga berlaku pada proses pertanggungjawaban pelaku usaha apabila melakukan wanprestasi terhadap perjanjian jual-beli yang telah disepakati bersama konsumen;

Masyarakat sekaligus berperan sebagai konsumen e-commerce jangan hanya tergiur harga murah namun juga harus lebih jeli, teliti dan paham bagaimana sistem jual-beli melalui e-commerce. Ini berhubungan pula dengan hak yang dimiliki konsumen guna mempertahankan dan menegakkan haknya sebagai pengguna produk.

\section{KESIMPULAN}

Bagi konsumen agar lebih berhati-hati dalam melakukan transaksi ecommerce, mengingat antara kosnumen dan pelaku usaha tidak saling bertatap muka dan tidak saling mengenal, maka tindak kecurangan dari pelaku usaha yang tidak beretikad baik akan lebih mudah muncul. Oleh karena itu, perlu sikap teliti serta waspada dari kosumen dalam melakukan kesepakatan dalam transaksi ecommerce.

bagi Pelaku Usaha agar tidak melakukan tindakan wanprestasi guna memperoleh keuntungan yang berlebih. Dasar dalam membuka usaha e-commerce adalah "kepercayaan" (trust) dari konsumen, oleh karena itu, pelayanan dengan kualitas yang tinggi serta etikad baik dalam melakukan usaha dalam $e$ commerce sangat dibutuhkan untuk menunjang keberhasilan usaha dari pelaku usaha $e$-commerce tersebut

\section{DAFTAR PUSTAKA}

\section{Buku}

Kasil, C.S.T., 1986, Pengantar Ilmu Hukum dan Tata Hukum Indonesia, Jakarta, Balai Pustaka.

Mahmud Marzuki, Peter, 2005, Penelitian Hukum, Jakarta, Kencana.

Trisiwikristiyanti, celine, 2017, Hukum Perlindungan Konsumen, Jakarta, Sinar Grafika.

W.Purbo Onno dan Aang Arif Wahyudi, Mengenal E-Commerce, Jakarta: Elex Media Komputindo, 2001.

Nasution, Az, Hukum Perlindungan Konsumen Suatu Pengantar, Jakarta: Dia dit, 2011.

\section{Jurnal}

Mantri, B.H. (2007). Perlindungan Hukum Terhadap Konsumen Dalam Transaksi E- Commerce. Jurnal Law Reform $3(1)$. 
Jurnal Analogi Hukum, Volume 1, Nomor 2, 2019.CC-BY-SA4.0License.

Sjahputra,1. (2010). Perlindungan Konsumen dalam Transaksi Elektronik. Bandung:Alumni.

Pebrian Perdana (2017). Implementation Of Good Governance Principles (Case Studies in Structural Echelon II Appointment Process in the City of Bandar Lampung Government). Jurnal Inovasi Pembangunan, Volume 05 No. $1(81)$.

\section{Internet}

http://www.hukumonline.com/klinil/detail/ c15517/e-padatanggal 4agustus2015

http://www.hukumonline.com/klinik/detail /it50bf69280b1ee/perlindungan-

hukum-bagi-konsumenbelanja-online

\section{Peraturan Perundang-Undangan}

Kitab Undang-Undang Hukum Perdata Undang-Undang Nomor 8 Tahun 1999 Tentang Perlindungan Konsumen.

Undang-Undang Nomor 11 Tahun 2008 tentang informasi dan transaksi elektronik.

Perturan Perundang-undangan No.82 Tahun 2012 Tentang Penyelenggaraan Sistem dan Transaksi Elektronik. 
